\title{
Bile Duct Hemorrhage
}

National Cancer Institute

\section{Source}

National Cancer Institute. Bile Duct Hemorrhage. NCI Thesaurus. Code C78334.

Bleeding originating from the bile duct. 